\title{
Petrographic controls on phosphorous distribution in coal seams of the Jharia basin, India
}

\author{
Atul Kumar Varma ${ }^{1, *}$, Sumit Mishra ${ }^{1}$, Balram Tiwari ${ }^{1}$, Bodhisatwa Hazra ${ }^{1}$, \\ Susheel Kumar ${ }^{1}$, Durga Charan Panigrahi ${ }^{2}$ and Anwita Ojha ${ }^{1}$ \\ ${ }^{1}$ Coal Geology and Organic Petrology Laboratory, Department of Applied Geology, Indian Institute of Technology \\ (Indian School of Mines), Dhanbad, India. \\ ${ }^{2}$ Department of Mining Engineering, Indian Institute of Technology (Indian School of Mines), Dhanbad, India. \\ ${ }^{*}$ Corresponding author. e-mail: atulvarma@hotmail.com
}

MS received 11 November 2017; revised 25 August 2018; accepted 2 October 2018; published online 6 April 2019

In recent years, the international coking coal market is experiencing an acute shortage of coal supply which has caused a fluctuation in its price. Degradation of coke, in the blast furnace, is largely controlled by its inherent mineral matter. Phosphorous occurs in all coals in minor or trace amounts and is an important parameter to coal users, particularly in steel industries. The mode of occurrence and distribution of phosphorous minerals in 17 coal samples of the Jharia coal basin were investigated through petrographic examinations, technological characterisation and phosphorous distribution. The results reveal that the dull bands are eight times more enriched in phosphorous than the bright bands. The macerals of the inertinite group and mineral matter positively correlate with the phosphorous content, whereas vitrinite macerals have an apathetic correlation. The impact of the thermal alterations is localised and diminishes away from the contact of the intrusion. In contrast, the faulting does not appear to have any effect on the phosphorous content.

Keywords. Dull band; bright band; phosphorous; maceral; dyke.

\section{Introduction}

Phosphorous, which is a very important biogenic element and is essential for all living cells, is observed to be around 10 times more concentrated in many present-day plants and dried modern plants than in coal (Francis 1961). Phosphorous is released from the plant structure and, in many cases, re-precipitated elsewhere in the peat bed by processes associated with organic decay (Swain 1970; Ward et al. 1996). Swain (1970) observed that phosphorous breaks down to orthophosphate $\left(\mathrm{HPO}_{4}^{-}\right)$and is removed from rotting vegetation. Phosphorous dissolves more in acid environments than in ferric iron (Patrick and Khalid 1974). Ionic potential provides a better understanding of the organic and inorganic affinities of phosphorous (Powell 1987). Bertine and Goldberg (1971) estimated the average phosphorous content of coal to be $0.05 \%$ or $500 \mathrm{ppm}$ on a worldwide basis. Although this is close to the average phosphorous content of $420 \mathrm{ppm}(0.042 \%)$ for sedimentary rocks (Ronov and Korzina 1960), it is less than 700 ppm $(0.07 \%)$ for soils (Swaine 1980). There have been a number of studies investigating the distribution of phosphorous in coal in order to classify them into those having organic and inorganic affinities. Although the occurrence of phosphorous-bearing 
organic compounds (phospho-proteins) in plant tissues is well known, there is no direct evidence of organically bound phosphorous in coal (Burchill et al. 1990). Swaine (1990) also observed the possibility of organic phosphorous compounds in coal, but the bulk of phosphorous is generally thought to be present as inorganic mineral components. Phosphorous, although generally low in concentration in coal, is a significant factor in the marketing and utilization of coking coals (Ward et al. 1996). Phosphorous in steel is known to reduce its flexibility and toughness, thereby increasing the possibility of breakage during processing, fabrication and service. It is therefore generally considered to be an undesirable element in coal (Bloom et al. 1990; Ryan and Khan 1997). Virtually all phosphorous in coal is transferred to coke during coke production and interacts with the iron ore (Mahony et al. 1981; Ward et al. 1996) during steel production. Phosphorous also causes intergranular segregation in the process of continuous casting and deteriorates the ductility and toughness of products (Marique and Nilles 1984). Moreover, it is also known to form superheater deposits in certain types of boilers (Burchill et al. 1990) and is also reported to poison the catalysts in liquefaction processes (Kovach and Bennett 1975). Phosphorous provides brittleness to steel due to its presence as an oxide impurity, whereas desired concentration of phosphorous is necessary in maintaining high-quality steels (Stubbles 1986). Phosphorous content entering the hot metal can be estimated as it is all retained in the coke (Mahony et al. 1981) and therefore it is possible to calculate the phosphorous content in the coke by an estimate of coke yield in the samples. Significant works on the phosphorous content of coals have been carried out by many workers, viz., Gluskoter et al. (1977), Zhou et al. (1982), Kilby (1986), Hill (1988), Burchill et al. (1990), Goodarzi et al. (1990), Bohor and Triplehorn (1993), Raza et al. (1995), Ryan and Boehner (1995), Ward et al. (1996), Ward (2016), Seredin (1996), Rao and Walsh (1997, 1999), Hower et al. (1999), Burger et al. (2000, 2002), Willett et al. (2000), Mardon and Hower (2004), Dai et al. (2012a), Moore and Esmaeili (2012), Seredin and Dai (2012), Spears (2012) and Dai et al. (2015a). Apatite is the most common phosphorous-bearing minerals found in coal (Ward et al. 1996; Ward 2002; Querol et al. 1997; Reifenstein et al. 1999; Wang 2009; Hackley et al. 2005; Kalkreuth et al. 2006; Dawson et al. 2012; Hower et al. 2012). In addition to apatite, Mahony et al. (1981) noted the presence of evansite and wavellite in some British coals. Mackowsky (1968), in some European coal samples, described the occurrence of non-crystalline phosphate gel or cellophane. Moreover, aluminophosphate minerals of goyazite group have been reported in the residues of a numbers of Australian coal samples by X-ray diffraction studies of low temperature (oxygen plasma) ash (Ward 1974, 1978). These represent a range of solid solutions involving members of the goyazitegorceixite-crandallite-florencite group (Finkelman and Stanton 1978; Crowley et al. 1993; Creelman and Ward 1996; Ward et al. 1996; Rao and Walsh 1997, 1999; Alastuey et al. 2001; Dai et al. 2012b, 2015b). Skeletal fragments and coprolite particles rich in phosphate may also be present in coal in some cases (Diessel 1992). Electron microscope and optical studies indicate that the aluminophosphates and phosphates in many coals occur as pore and cell infillings (Cook 1962; Ward et al. 1996; Rao and Walsh 1999). Dai et al. (2016) observed the abundance of cavities in inertinites in comparison with vitrinite macerals, making more channels available for water movement and pore spaces for subsequent mineral deposition. Information on the mineral matter in coal is helpful in estimating the likely effects of beneficiation on trace-element reductions (Huggins et al. 1993; Singh et al. 2010; Prachiti et al. 2011; Singh et al. 2015a, b, 2016a, b). Furthermore, the knowledge of the minerals and their characteristics of the relevant feed coal can be used to provide a basis for understanding the interactions they may have in different coal utilisation processes (Singh and Singh 1995; Singh et al. 2015a; Dai et al. 2016; Hower et al. 2016; Ward 2016). Phosphorous content of coals varies geographically through geological time. Cretaceous coals from Western Canada and Permian coals from India and Australia have higher phosphorous concentrations than carboniferous coals from USA and Europe (Ryan and Grieve 1996; Ward et al. 1996; Varma and Mishra 2005). However, very little information is available related to phosphorous content of Indian coals (Varma and Mishra 2005; Prachiti et al. 2011). Authors have chosen 17 coal samples belonging to the Barakar Formation of Lower Permian age of the Jharia basin to investigate nature and occurrence of phosphorous. Special emphasis is given on the occurrence of phosphorous in dull and bright bands within the samples, effect of faulting and igneous intrusion on phosphorous content of coals. 


\section{Geological setting}

The Jharia coal basin is located in the Dhanbad district of Jharkhand state, and it is the prime source of coking coal in India. The coal basin is a Gondwana sedimentary basin of the Damodar valley of eastern India (Fox 1930; Mehta and Murthy 1957). The field is roughly sickle shaped and has an areal extent of about $458 \mathrm{~km}^{2}$ with about $40 \mathrm{~km}$ length in the east-west direction and about $20 \mathrm{~km}$ width in the north-south direction (figure 1; Fox 1930; Chandra 1992). Overlying the Archaean basement, unconformably, the sedimentary sequence of this basin has the Talchir Formation at its base, which is, successively, overlain by the fluvial as well as fluvio-lacustrine sediments of the Barakar, the Barren Measures and the Raniganj Formations (Fox 1930; Mehta and Murthy 1957; Sengupta et al. 1979). The sediments are deposited within an intracratonic extensional setting (Ghosh and Mukhopadhyay 1985). The Barakar Formation with 18 persistent seams and Raniganj Formation with 12 persistent seams are the main coal-bearing formations (Fox 1930). In the Barakar Formation, Fox (1930) had identified 18 coal seams from bottom to top starting with seam I to seam XVIII. However, 46 seams have been reported later by Verma et al. (1989) in the Barakar Formation including 18 major seams and 5 local seams, and the remaining 23 seams are actually the splits of the major seams. The coal seams are affected by faults that are of both post- and syn-depositional origins (Ghosh and Mukhopadhyay 1985). The Barren Measures Formation outcrops in the central part of the basin and has a thickness of $750 \mathrm{~m}$.

The regional faults against the lithology of the Barakar Formation demarcate the northern

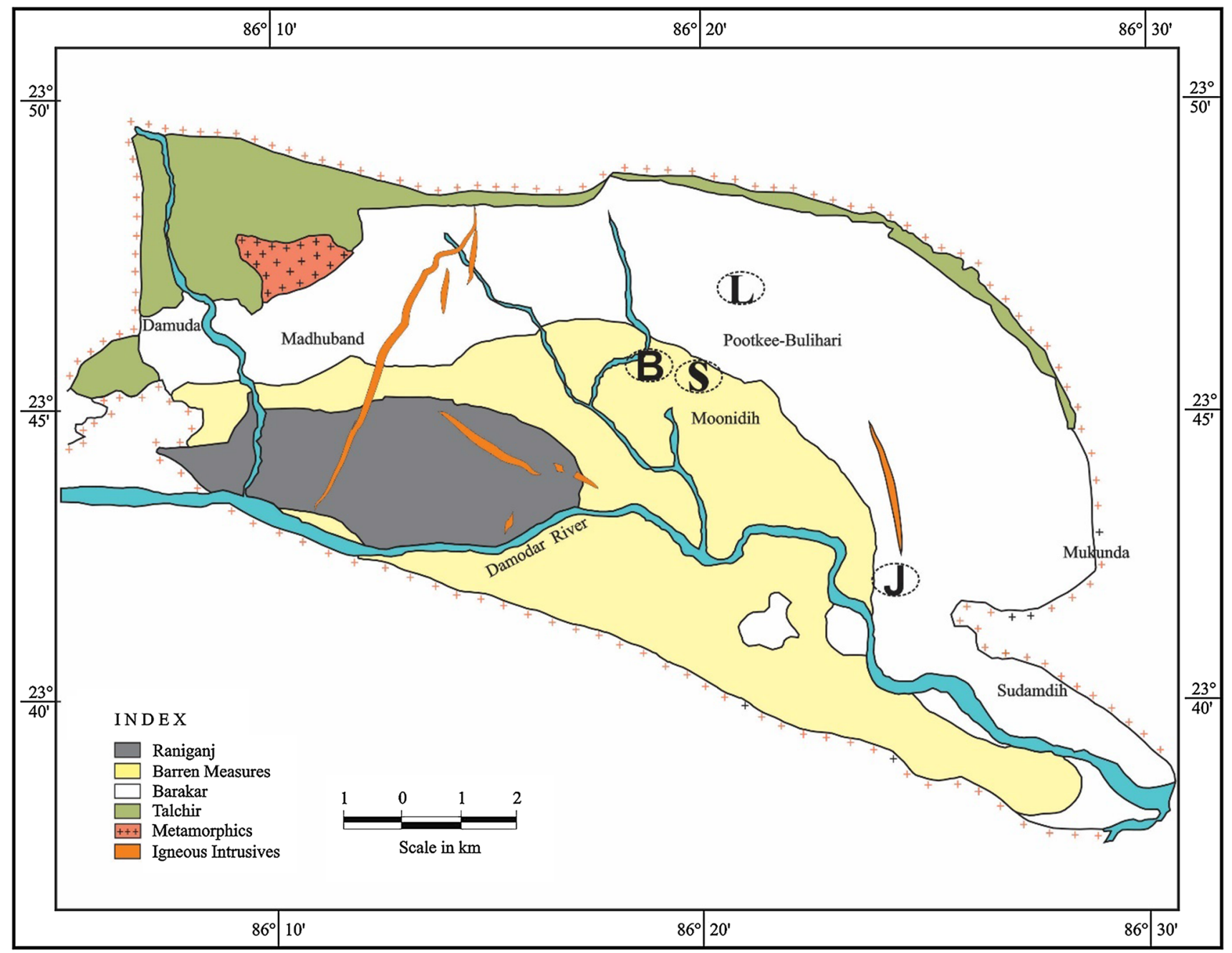

Figure 1. Geological map of the Jharia coal basin (Fox 1930; Verma et al. 1989; Chandra 1992; CIL 1993). The study areas are shown in the map. B: Bhelatand colliery; J: Jamadoba colliery; L: Loyabad colliery; S: Sijua colliery. 
Table 1. Generalised stratigraphic succession of the Jharia coal basin (Mukhopadhyay et al. 2010).

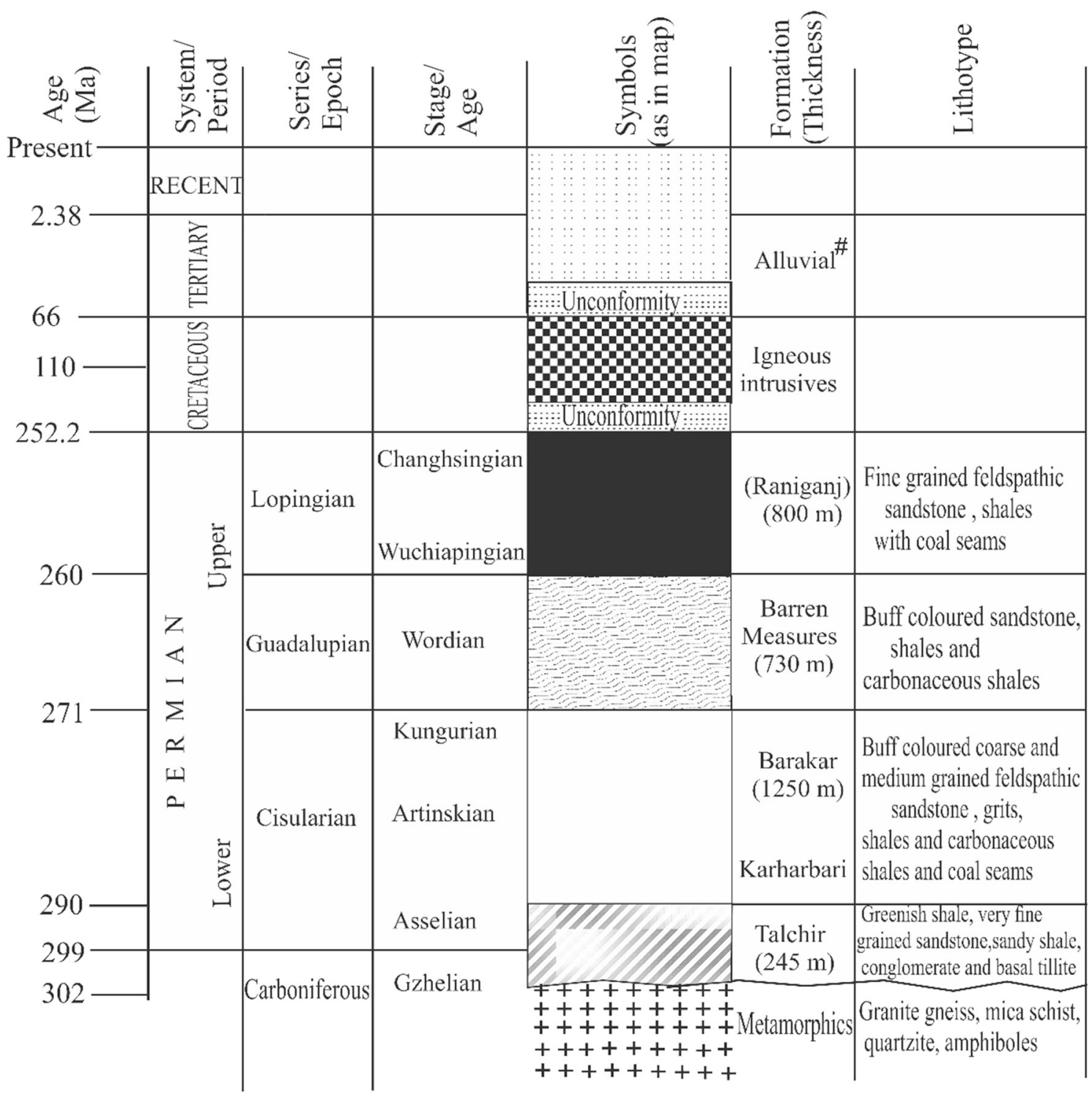

and eastern boundaries of the basin (Fox 1930; Ghosh and Mukhopadhyay 1985). The generalised lithostratigraphic succession of the Jharia coal basin is shown in table 1 (Fox 1930; Chandra 1992; Mukhopadhyay et al. 2010).

\section{Materials and methods}

\subsection{Collection of samples}

Samples were collected from the Jamadoba $(\mathrm{J})$, Sijua (S), Bhelatand (B) and Loyabad (L) collieries of the Jharia basin. A total of 17 coal samples including four igneous intrusive affected samples and two samples in proximity to a fault were collected through channel sampling methods following ASTM (2015). The location of the samples is provided in figure 1. Dull and bright bands were manually separated following the classification system suggested by Thiessen (1920) and Francis (1960) from samples JJ14, JJ16, JS11, JS12, JB13 and JB15 to see the distribution of phosphorous.

\subsection{Technological properties}

The technological properties, viz., moisture content $\left(W^{\mathrm{a}}\right)$, ash yield $\left(A^{\mathrm{d}}\right)$, volatile matter yield $\left(\mathrm{VM}^{\mathrm{daf}}\right)$ and fixed carbon content were determined for the coal samples following the IS (1984). 


\subsection{Micropetrographic analysis}

Coal samples were crushed to $<1 \mathrm{~mm}$ size to prepare pellets and were studied under reflected light with a 'Leitz MPV2' reflectance microscope with an oil immersion lens and fluorescence attachment following standard procedures (ICCP 1971, 1998, 2001) at Coal Geology and Organic Petrology Laboratory, Department of Applied Geology, Indian Institute of Technology (Indian School of Mines), Dhanbad, India, and macerals were identified following ICCP classification of macerals (ICCP 1971, 1998, 2001). The vitrinite reflectance measurements were carried out on prepared coal pellets (ASTM 1994).

\subsection{Phosphorous determination}

The gravimetric (phosphomolybdate) method (IS 1979) was applied to determine the content of phosphorous. In the adopted method, it is assumed that the total phosphorous is retained in the ash. In this procedure, sample of the coal is completely burnt into ash as specified in IS (1984). The extraction was carried out. First, the ash was powdered in an agate mortar to pass through $63-\mu \mathrm{m}$ IS sieve. A preliminary determination is carried out using $0.5 \mathrm{~g}$ of ash, and depending upon the phosphorous content, an appropriate quantity of the ash $(0.5-4 \mathrm{~g})$ is weighed into a platinum crucible of about $30 \mathrm{ml}$ capacity following the standard. Then, $10 \mathrm{ml}$ concentrated nitric acid solution and $5 \mathrm{ml}$ of hydrofluoric acid solution were added and left for 45 min to dry. To ensure the complete removal of the hydrofluoric acid, further $5 \mathrm{ml}$ of concentrated nitric acid was again added and left to dry. Furthermore, $15 \mathrm{ml}$ of dilute nitric acid solution was added and evaporated until it becomes to about $7 \mathrm{ml}$. The solution was then transferred to a 250 $\mathrm{ml}$ beaker, and the washings of the crucible were added to it, so that the combined volume of the washings and the original solution was $80 \mathrm{ml}$. Then beaker is covered with a clock glass and is boiled for $15 \mathrm{~min}$. The extract obtained is filtered with a filter paper into a 40-ml beaker and washed with water until $10 \mathrm{ml}$ of remaining washings give an alkaline reaction with final volume of the filtrate up to $250 \mathrm{ml}$. Afterwards, the solution was evaporated to about $50 \mathrm{ml}$, and the concentrated ammonium hydroxide solution was added till the precipitate of iron and aluminium hydroxide appears. Then precipitate was redissolved by adding concentrated nitric acid and the excess of concentrated nitric acid solution and 3-4 g of potassium nitrate were added. The volume of the liquid should not now exceed $70 \mathrm{ml}$. The solution is then heated to $75^{\circ} \mathrm{C}$ with subsequent addition of ammonium molybdate solution and maintained at $50^{\circ} \mathrm{C}$ for 30 min. The beaker containing the phosphomolybdate precipitate was kept with stirring for about $2.5 \mathrm{hr}$ at room temperature $\left(25-30^{\circ} \mathrm{C}\right)$ and allowed to settle down, and then the precipitate was filtered through the weighed sintered-glass crucible. Finally, the phosphomolybdate precipitate was washed four times with weak nitric acid solution (II), using $15 \mathrm{ml}$ each time, two times with dilute ammonium nitrate solution, using $15 \mathrm{ml}$ each time, two times with water, using $5 \mathrm{ml}$ each time and, finally, three times with absolute alcohol using $3 \mathrm{ml}$ each time. Later, it was dried at $125-130^{\circ} \mathrm{C}$ in an oven for $30 \mathrm{~min}$ and cooled in a freshly charged desiccator containing concentrated sulphuric acid solution. A blank determination was carried out in the same way as described above but by the substitution of a pure phosphorous compound diluted to contain an amount of phosphorous approximately equal to that in the ash.

Phosphorous content is calculated in ash yield in the following equation:

$$
(A)=1.65[X-(V-60.6 Z) / M],
$$

where $A$ is the mass of the phosphomolybdate precipitation $g, V$ the mass of the phosphomolybdate precipitate obtained from the pure phosphorous compounding $g, Z$ the calculated mass of the phosphorous taken for the blank determination in $g$ and $M$ the mass of the ash yield taken for the testing.

The phosphorous content in coal is determined by the following equation:

$$
(P)=0.01 \times A \times C,
$$

where $P$ is the phosphorous content in coal (wt\%), $A$ the mass of phosphorous in ash (wt\%) and $C$ the ash yield of coal (wt\%).

\section{Results and discussion}

The results related to technological properties of the collected coal samples of the Jharia basin show a significant relation with the phosphorous content (table 2). The ash yield (dry basis) for the studied coal samples varies from 15.56 to 27.02 wt $\%$ and the phosphorous content ranges between 0.030 and $0.284 \mathrm{wt} \%$ and exhibits a strong positive 


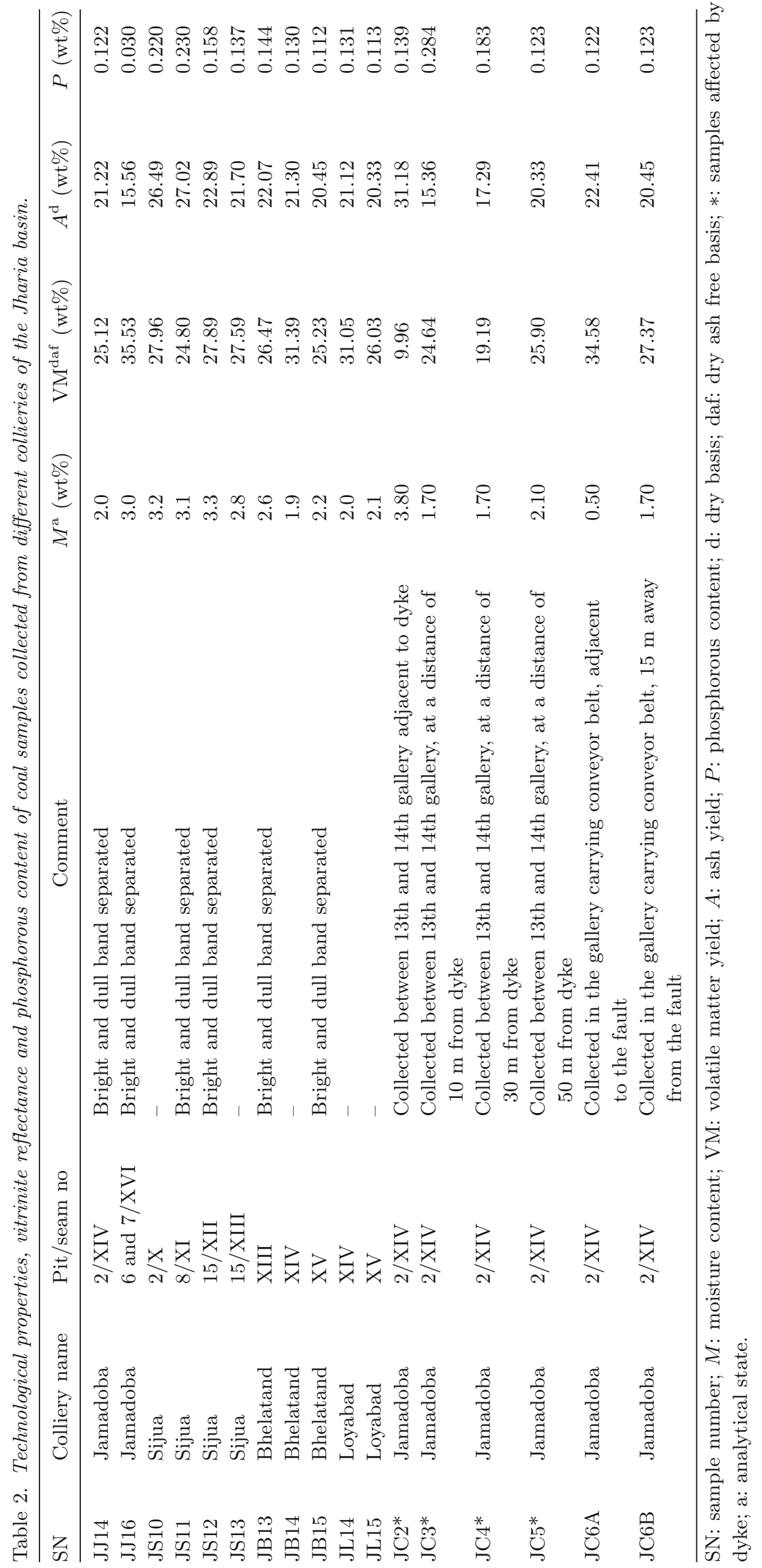


correlation with phosphorous content $\left(R^{2}=0.99\right.$; figure 2). The phosphorous content is mainly concentrated in ash yield derived from the mineral matter content of the coal (Gentzis and Godarzi 1997). Furthermore, the trace-element content in coal or in ash increases with an increase in ash yield, indicating their mineral-matter association (Clark and Swaine 1962; Prachiti et al. 2011; Singh et al. 2015b, 2016b). Relationship between phosphorous content in the separated bright and dull bands of few samples (JJ14, JJ16, JS11, JS12, JB13 and JB15; table 3) revealed that the bright bands

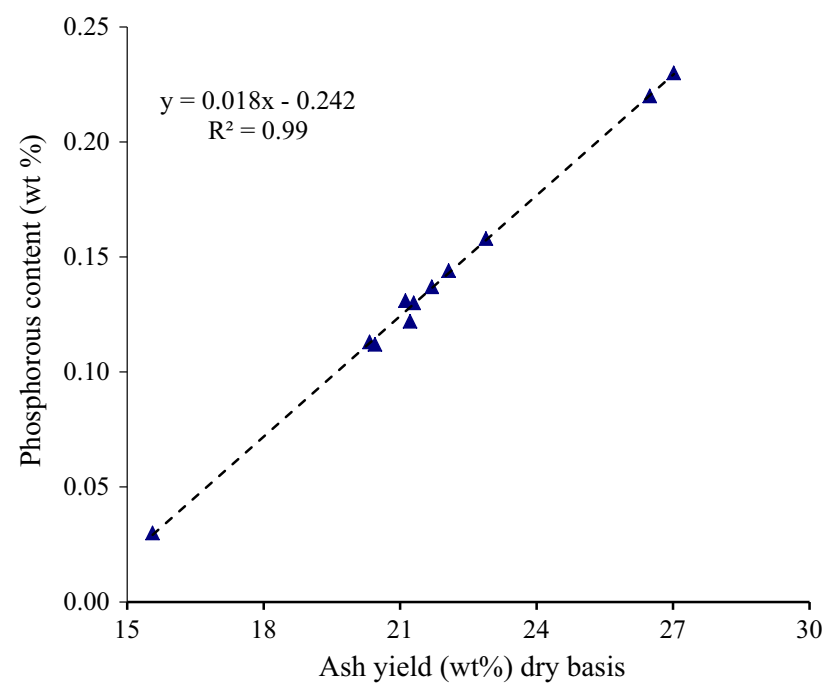

Figure 2. Relationship between the phosphorous content (wt\%) and ash yield (wt\%). of the samples contain approximately eight times less phosphorous than the dull bands.

This may be explained as dull bands, in contrast to bright bands, chiefly contain inertinite macerals. Moreover, the dull bands are also marked by larger ash yield compared to the bright bands (table 3 ). A similar positive correlation between the phosphorous concentration and dull bands was observed by Harris et al. (1981). Berger (1958) has also noticed 8-10 times more concentration of phosphorous in dull bands as compared to that in bright bands in the case of Russian coals, which are rich in inertinite macerals. The above observation is further supported with the micropetrographic results taken into consideration. The results related to micropetrographic analysis are given in table 4 . The total content of vitrinite macerals exhibits a strong negative relation with phosphorous content $\left(R^{2}=0.95\right.$; figure 3$)$, whereas the total content of inertinite macerals shows a strong positive relation with phosphorous content $\left(R^{2}=0.94\right.$; figure 4$)$. Gluskoter et al. (1977) elucidated that the phosphorous is preferentially concentrated in inertinite maceral, which indicates that the inorganic matter is a significant factor in controlling the phosphorous concentration. Moreover, the total amount of mineral-matter content (wt\%) determined through micropetrographic analysis also shows a strong positive relation with the phosphorous content $\left(R^{2}=0.91\right.$; figure 5$)$. These results indicate the inorganic nature of phosphorous mainly within the

Table 3. Technological properties and phosphorous content of bright and dull bands (separately) of individual coal samples.

\begin{tabular}{llcccc}
\hline SN & Lithotype & $M^{\mathrm{a}}(\mathrm{wt} \%)$ & $\mathrm{VM}^{\mathrm{daf}}(\mathrm{wt} \%)$ & $A^{\mathrm{d}}(\mathrm{wt} \%)$ & $P(\mathrm{wt} \%)$ \\
\hline \multirow{2}{*}{ JJ14 } & Bright band & 2.00 & 24.22 & 14.90 & 0.025 \\
& Dull band & 1.70 & 24.32 & 21.36 & 0.200 \\
\multirow{2}{*}{ JJ16 } & Bright band & 2.80 & 32.26 & 10.08 & 0.006 \\
& Dull band & 2.90 & 36.72 & 16.99 & 0.047 \\
\multirow{2}{*}{ JS11 } & Bright band & 3.00 & 23.92 & 15.51 & 0.040 \\
& Dull band & 3.10 & 24.33 & 27.04 & 0.357 \\
\multirow{2}{*}{ JS12 } & Bright band & 3.20 & 22.46 & 14.46 & 0.027 \\
& Dull band & 3.00 & 27.42 & 24.79 & 0.245 \\
\multirow{2}{*}{ JB13 } & Bright band & 2.50 & 22.59 & 12.82 & 0.037 \\
& Dull band & 2.45 & 26.27 & 21.56 & 0.305 \\
JB15 & Bright band & 2.20 & 21.57 & 11.35 & 0.027 \\
& Dull band & 2.00 & 26.58 & 17.68 & 0.239 \\
\hline
\end{tabular}

SN: sample number; $M$ : moisture content; VM: volatile matter yield; $A$ : ash yield;

FC: fixed carbon content; d: dry basis; daf: dry ash free basis; a: analytical state;

$P$ : phosphorous content. 


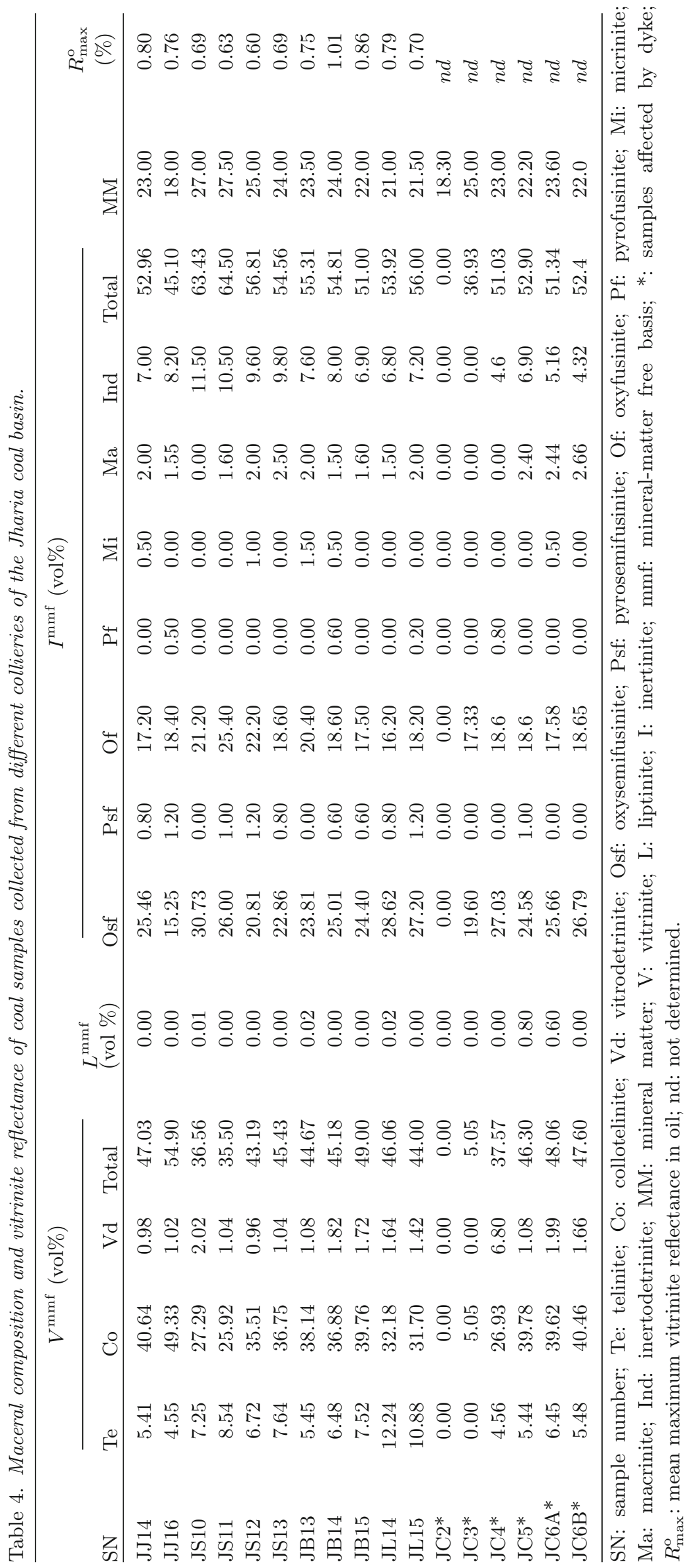




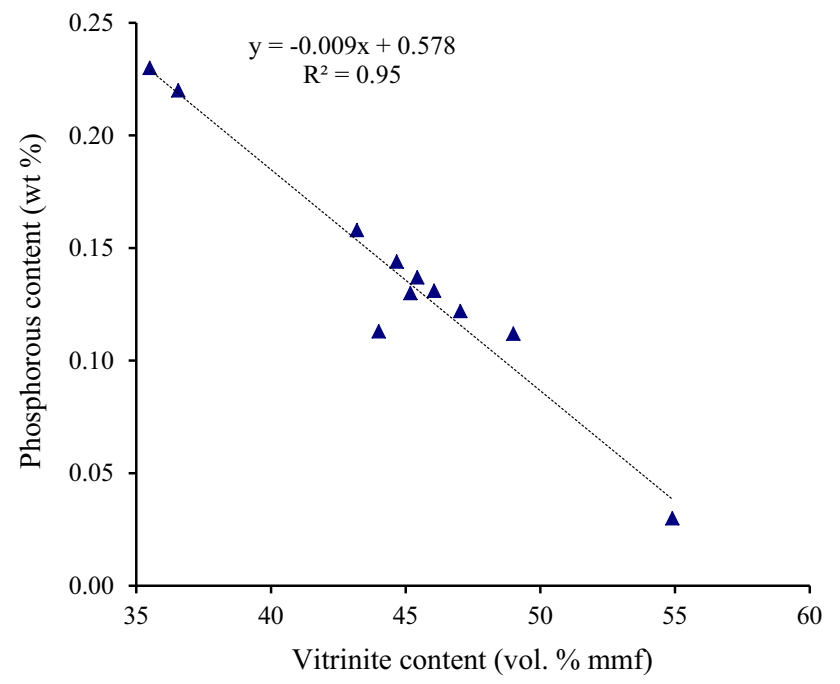

Figure 3. Relationship between the phosphorous content and vitrinite maceral content (vol\%).

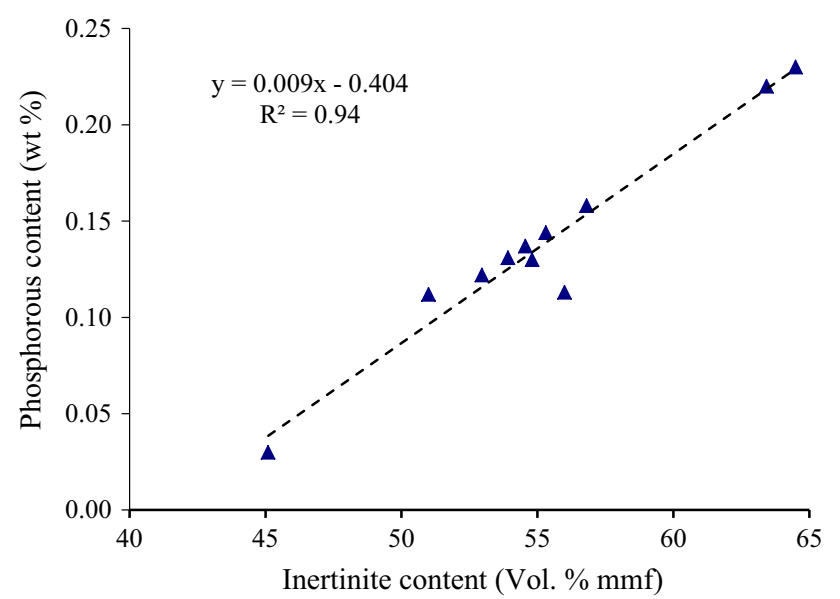

Figure 4. Relationship between the phosphorous content and inertinite macerals (vol\%).

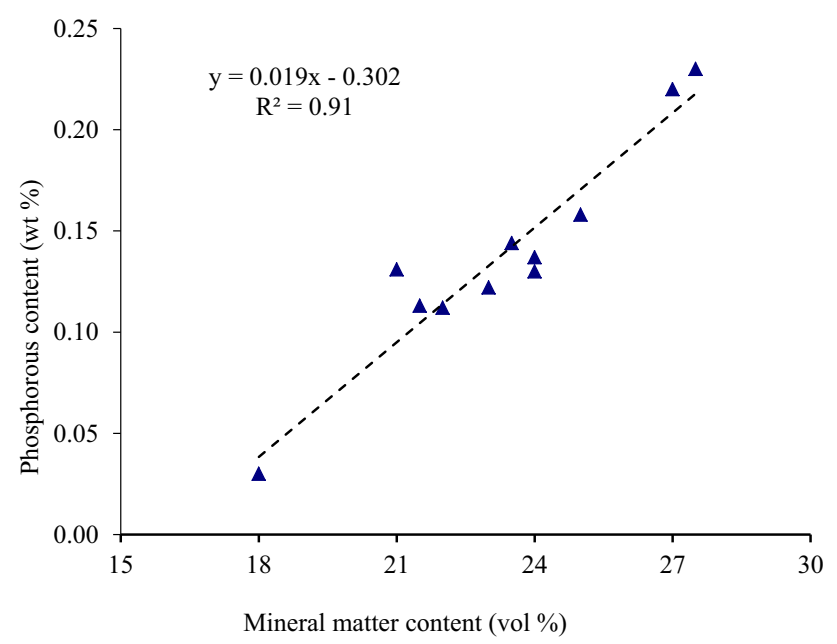

Figure 5. Relationship between the phosphorous content (wt\%) and petrographically visible mineral matter content (vol\%). studied coals, which are typically more concentrated within the dull bands and are associated with the inertinite macerals. The vitrinite $\left(V \mathrm{t}^{\mathrm{mmf}}\right)$ and inertinite $\left(I^{\mathrm{mmf}}\right)$ contents of coal samples in the studied area vary from 35.50 to 54.90 and 45.10 to 65.50 vol\%, respectively (table 2). Liptinite of macerals was identified only in traces in all the coal samples. The mean maximum vitrinite reflectance $\left(R^{\circ} \max \right)$ was determined for JJ14, JJ16, JS10, JS11, JS12, JS13, JB13, JB14, JB15, JL14 and JL15 coal samples (table 2) and was varied between 0.60 and $1.00 \%$. The technological properties of coal samples also reveal that sample $\mathrm{JC}^{*}$, in immediate contact with the dyke, is marked by least volatile matter yield (9.96 wt\%, dry ash free basis; table 2) and largest fixed carbon content (90.04 wt\%; daf basis), which might have been caused due to the impact of the intruded dyke. The ash yield was observed to increase from 15.36 wt\% (dry basis) in sample JC3* to 31.18 wt\% (dry basis) in sample $\mathrm{JC} 2 *$ (in immediate contact with the intrusion). The large ash yield in sample $\mathrm{JC}^{*}$ * might have been caused due to the secondary mineralisation that may have taken place due to the impact of the intrusion (Finkelman et al. 1998). Mastalerz et al. (2009) and Schimmelmann et al. (2009) have also observed the presence of carbonates within coal seams associated with igneous intrusions, which might have been formed from the hydrothermal solutions. Sample JC3*, which is at a distance of $10 \mathrm{~m}$ from the dyke, shows the largest phosphorous content ( $0.284 \mathrm{wt} \%$; table 2$)$, indicating that the chemical fluids might have migrated from the dyke. Samples JC3* $(1.70 \mathrm{wt} \%)$ and JC4* $(1.70 \mathrm{wt} \%)$ adjacent to the dyke correspond to the lowest moisture content among the heat-affected samples (table 2). The effect of intruded dyke is manifested with the decrease in the moisture and volatiles with concomitant increase in the ash yield, fixed carbon and phosphorous content. The coal seams adjacent to the intrusion are converted to jhama (natural coke). The impact of dyke is confined to a short distance, and the effect of heat dies out away from the dyke. The phosphorous concentration decreases as the distance from the dyke increases to $30-40 \mathrm{~m}$. The concentration of phosphorous in sample JC6A (collected adjacent to the fault) is $0.122 \mathrm{wt} \%$, whereas the concentration in sample JC6B (collected $15 \mathrm{~m}$ away from fault) was observed to be $0.123 \mathrm{wt} \%$ (table 4). It seems that the faulting has no effect on the phosphorous concentration. Steel industries are developing strategies to limit the phosphorous content in coal 
that is used for making steel. This study overall provides an insight into the inorganic nature of phosphorous, which may be helpful for steel industry in targeting the coal seams of the basin having lower phosphorous content. The study also points towards the concentration of phosphorous in coal seam near to lamprophyre dyke and in dull bands/inertinites.

\section{Conclusions}

- The relationship of phosphorous content with ash yield and mineral matter content indicates its inorganic nature.

- The phosphorous content is mainly concentrated in dull bands.

- The intertinite macerals provide suitable environment for deposition of phosphorous minerals.

\section{Acknowledgements}

The authors are thankful to the Deputy Director General, Coal Wing, Geological Survey of India, Kolkata, for providing permission to use his laboratory facility for vitrinite reflectance measurements. The authors are indebted to Mr Santanu Ghosh, Department of Applied Geology, Indian Institute of Technology (Indian School of Mines), Dhanbad, India, for his help in correcting and improving the quality of paper. The authors would like to convey their sincere thanks to Prof Partha Pratim Chakraborty, Associate Editor, Journal of Earth System Science, and the learned reviewers for their valuable suggestions to upgrade the quality of this paper.

\section{References}

Alastuey A, Jiménez A, Plana F, Querol X and Suárez-Ruiz I 2001 Geochemistry, mineralogy, and technological properties of the main Stephanian carboniferous coal seams from the Puertollano basin, Spain; Int. J. Coal Geol. 45 $247-265$.

ASTM 1994 D 2798-96. Standard test method for microscopical determination of the reflectance of vitrinite in a polished specimen of coal; Annual Book of American Society for Testing and Materials Standards: Gaseous fuels: Coal and coke; Sect 5, Vol. 5.05, pp. 279-283.

ASTM 2015 D 4596-09. Standard practice for collection of channel samples of coal in a mine (Reapproved); Annual Book of American Society for Testing and Materials Standards, 3p.

Berger I A 1958 Geochemistry of coal; Econ. Geol. 53 823841.
Bertine K K and Goldberg E D 1971 Fossil fuel combustion and the major sedimentary cycle; Science 173 233-235.

Bloom T A, Fosnacht D R and Haezebrouck D M 1990 The influence of phosphorus on the properties of sheet steel products and methods used to control steel phosphorus levels in steel product manufacturing - Part I; Iron Steelmaker 18 35-41.

Bohor B F and Triplehorn D M 1993 Tonsteins: Altered volcanic ash layers in coal bearing sequences; Geol. Soc. Am. Spec. Paper 28544.

Burchill P, Howarth O W, Richards D G and Sword B J 1990 Solid-state nuclear magnetic resonance studies of phosphorus and boron in coals and combustion residues; Fuel 69 421-428.

Burger K, Bandelow F K and Bieg G 2000 Pyroclastic kaolin coal-tonsteins of the upper Carboniferous of Zonguldak and Amasra, Turkey; Int. J. Coal Geol. 45 39-53.

Burger K, Zhou Y and Ren Y 2002 Petrography and geochemistry of tonsteins from the 4th Member of the Upper Triassic Xujiahe formation in southern Sichuan Province, China; Int. J. Coal Geol. 49 1-17.

Chandra D 1992 Jharia coalfield. Mineral resources in India; Vol. 5, Geological Society of India, Bangalore, 149p.

CIL 1993 Coal atlas of India; Coal India Limited, Calcutta, pp. 84-85.

Clark M C and Swaine D J 1962 The contents of several trace elements in the standard rocks G-1 and W-1; Cosmochim. Acta 26 511-514.

Cook A C 1962 Fluorapatite petrifactions in a Queensland coal; Austr. J. Sci. 2594.

Creelman R A and Ward C R 1996 A scanning electron microscope method for automated, quantitative analysis of mineral matter in coal; Int. J. Coal Geol. 30 249-269.

Crowley S S, Ruppert L F, Belkin H E, Stanton R W and Moore T A 1993 Factors affecting the geochemistry of a thick, sub-bituminous coal bed in the Powder River Basin: Volcanic, detrital, and peat forming processes; Org. Geochem. 20 843-853.

Dai S, Graham I T and Ward C R 2016 A review of anomalous rare earth elements and yttrium in coal; Int. J. Coal Geol. 159 82-95.

Dai S, Ren D, Chou C-L, Finkelman R B, Seredin V V and Zhou Y 2012a Geochemistry of trace elements in Chinese coals: A review of abundances, genetic types, impacts on human health, and industrial utilization; Int. J. Coal Geol. 94 3-21.

Dai S, Zou J, Jiang Y, Ward C R, Wang X, Li T, Xue W, Liu S, Tian H, Sun X and Zhou D 2012b Mineralogical and geochemical compositions of the Pennsylvanian coal in the Adaohai Mine, Daqingshan Coalfield, Inner Mongolia, China: Modes of occurrence and origin of diaspore, gorceixite, and ammonianillite; Int. J. Coal Geol. 94250 270.

Dai S, Li T, Jiang Y, Ward C R, Hower J C, Sun J, Liu J, Song H, Wei J, Li Q, Xie P and Huang Q 2015a Mineralogical and geochemical compositions of the Pennsylvanian coal in the Hailiushu Mine, Daqingshan Coalfield, Inner Mongolia, China: Implications of sediment source region and acid hydrothermal solutions; Int. J. Coal Geol. 137 92-110.

Dai S, Hower J C, Ward C R, Guo W, Song H, O'Keefe M K, Xie P, Hood M M and Yan X 2015b Elements and 
phosphorus minerals in the middle Jurassic inertinite rich coals of the Muli Coalfield on the Tibetan Plateau; Int. J. Coal Geol. 144-145 23-47.

Dawson G K W, Golding S D, Esterle J S and Massarotto P 2012 Occurrence of minerals within fractures and matrix of selected Bowen and Ruhr Basin coals; Int. J. Coal Geol. 94 150-166.

Diessel C F K 1992 Coal-bearing depositional systems; Springer-Verlag, Berlin, 721p.

Finkelman R B and Stanton R W 1978 Identification and significance of accessory minerals from a bituminous coal; Fuel 57 763-768.

Finkelman R B, Bostick N H, Dulong F T, Senftle F E and Thorpe A N 1998 Influence of an igneous intrusion on the inorganic geochemistry of a bituminous coal from Pitkin County, Colorado; Int. J. Coal Geol. 36 223-241.

Fox C S 1930 The Jharia coalfield; Mem. Geol. Surv. India 56248.

Francis W 1961 Coal: Its formation and composition; Edward Arnold, London.

Gentzis T and Godarzi F 1997 Trace elements geochemistry of brackish water coals in the central Alberta Plains, Canada; Energy Resour. 19 493-505.

Ghosh S K and Mukhopadhyay A 1985 Tectonic history of the Jharia basin - An intracratonic Gondwana Basin of eastern India; Quart. J. Geol. Min. Met. Soc. India 57 33-58.

Gluskoter J J, Ruch R R, Miller W G, Cahill R A, Dreher G B and Kuhn J K 1977 Trace elements in coal: Occurrence and distribution; Illinois State Geological Survey, Circular, 499p.

Goodarzi F, Grieve D A and Labonte M 1990 Tonsteins in East Kootenay coalfields, south eastern British Columbia; Energy Source 12 265-295.

Hackley P C, Warwick P D and González E 2005 Petrology, mineralogy and geochemistry of mined coals, western Venezuela; Int. J. Coal Geol. 63 68-97.

Harris L A, Barrett H E and Kopp O C 1981 Element concentrations and their distribution in two bituminous coals of different paleoenvironments; Int. J. Coal Geol. 1 175193.

Hill P A 1988 Tonsteins of Hat Creek, British Columbia: A preliminary study; Int. J. Coal Geol. 10 155-175.

Hower J C, Hoffman G K and Garrison T M 2012 Macrinite and funginite forms in Cretaceous Menefee Formation anthracite, Cerrillos coalfield, New Mexico; Int. J. Coal Geol. 114 54-59.

Hower J C, Ruppert L F and Eble C F 1999 Lanthanide, yttrium, and zirconium anomalies in the fire clay coal bed, eastern Kentucky; Int. J. Coal Geol. 39 141-154.

Hower J C, Eble C F, Dai S and Belkin H E 2016 Distribution of rare earth elements in eastern Kentucky coals: Indicators of multiple modes of enrichment? Int. J. Coal Geol. 160-161 73-81.

Huggins F E, Shah N, Zhao J, Lu F and Huffman G P 1993 Nondestructive determination of trace element speciation in coal and coal ash by XAFS spectroscopy; Energy Fuels 7 (4) 482-489.

ICCP 1971 International handbook of coal petrology (Suppl.) (2nd edn); International Committee for Coal Petrography, Cent. Natl. Rech. Sci., Paris.
ICCP 1998 The new vitrinite classification (ICCP system 1994). International Committee for Coal and Organic Petrology; Fuel 77 349-358.

ICCP 2001 The new inertinite classification (ICCP system 1994). International Committee for Coal and Organic Petrology; Fuel 80 459-471.

IS 1979 Indian standard Part V-1350: Methods of test for coal and coke special impurities (first revision).

IS 1984 Indian standard 1350-1: Methods of test for coal and coke, Part I: Proximate analysis (PCD 7: solid mineral fuels).

Kalkreuth W, Holz M, Kern M, Machado G, Mexias A, Silva M B, Willett J, Finkelman R and Burger H 2006 Petrology and chemistry of Permian coals from the Paraná Basin. 1. Santa Terezinha, Leão-Butiá and Candiota coalfields, Rio Grande do Sul, Brazil; Int. J. Coal Geol. 68 79-116.

Kilby W E 1986 Some chemical and mineralogical characteristics of tonsteins and bentonites in Northeast British Columbia Ministry of Energy; Mines and Petroleum Resources, Geological Fieldwork 1985, Paper 1986-1.

Kovach S M and Bennett J 1975 Coal liquefaction. 1. Catalysts present in coal; Am. Chem. Soc., Div. Fuel Chem. 20(1) 143-160.

Mackowsky M-Th 1968 Mineral matter in coal; In: Coal and coal-bearing strata (eds) Murchison D G and Westoll T S, Oliver and Boyd, London, pp. 309-321.

Mahony B, Moulston I and Wilkinson H C 1981 Study of the relationship between the phosphorus content of coal and coke; Fuel 60 355-358.

Mardon S M and Hower J C 2004 Impact of coal properties on coal combustion by-product quality: Examples from a Kentucky power plant; Int. J. Coal Geol. 59 153-169.

Marique C and Nilles P 1984 4th process technology conference on mixed gas blowing; Iron and Steel Society of AIME, Chicago, IL, 147p.

Mastalerz M, Drobniak A and Schimmelmann A 2009 Changes in optical properties, chemistry, and micropore and mesopore characteristics of bituminous coal at the contact with dikes in the Illinois Basin; Int. J. Coal Geol. 77 310-319.

Mehta D R S and Murthy B R N 1957 A revision of the geology and coal resources of the Jharia coalfield; Mem. Geol. Surv. India 84(2) 142.

Moore F and Esmaeili A 2012 Mineralogy and geochemistry of the coals from the Karmozd and Kiasar coal mines, Mazandaran province, Iran; Int. J. Coal Geol. 96-97 921.

Mukhopadhyay G, Mukhopadhyay S K, Roychowdhury M and Parui P K 2010 Stratigraphic correlation between different Gondwana basins of India; J. Geol. Soc. India $\mathbf{7 6}$ 251-266.

Patrick W H and Khalid R A 1974 Phosphate release and sorption by soils and sediments: Effect of aerobic and anaerobic conditions; Science 186 53-55.

Powell M A 1987 The inorganic geochemistry of two western U.S. coals: Emery coal field, Utah and Powder river coal field, Wyoming; unpublished $\mathrm{PhD}$ Thesis, University of Western Ontario, London, Ontario.

Prachiti P K, Manikyamba C, Singh P K, Balaram V, Lakshminarayana G, Raju K, Singh M P, Kalpana M S and Arora M 2011 Geochemical systematics and precious metal content of the sedimentary horizons of lower 
Gondwanas from the Sattupalli coal field, Godavari Valley, India; Int. J. Coal Geol. 88 83-100.

Querol X, Whateley M K G, Fernández-Turiel J L and Tuncali E 1997 Geological controls on the mineralogy and geochemistry of the Beypazari lignite, central Anatolia, Turkey; Int. J. Coal Geol. 33 255-271.

Rao P D and Walsh D E 1997 Nature and distribution of phosphorus minerals in Cook Inlet coals, Alaska; Int. J. Coal Geol. 33 19-42.

Rao P D and Walsh D E 1999 Influence of environments of coal deposition on phosphorous accumulation in a high latitude, northern Alaska, coal seam; Int. J. Coal Geol. 38 261-284.

Raza A, Hill K C and Korsch R J 1995 Mid-Cretaceous regional uplift and denudation of the Bowen-Surat basins, Queensland and its relation to Tasman sea rifting; In: Proceedings of the Bowen basin symposium (suppl.) (eds) Follington I W, Beeston J W and Hamilton L H, Geological Society of Australia, Queensland Division, Mackay, Queensland, pp. 1-8.

Reifenstein A P, Kahraman H, Coin C D A, Calos N J, Miller G and Uwins P 1999 Behaviour of selected minerals in an improved ash fusion test: Quartz, potassium feldspar, sodium feldspar, kaolinite, illite, calcite, dolomite, siderite, pyrite and apatite; Fuel 78 1449-1461.

Ronov A B and Korzina G A 1960 Phosphorus in sedimentary rocks; Geochemistry 8 805-829.

Ryan R J and Boehner R C 1995 Upper Paleozoic overlap assemblages: geological overview; In: Geology of the Appalachian-Caledonian Orogen in Canada (ed.) Williams H, Geological Survey of Canada, Geology of Canada, No. 6, Vol. F-1, pp. 782-783.

Ryan B and Grieve D A 1996 Source and distribution of phosphorus in British Columbia Coal Seams; In: Geological fieldwork 1995 (eds) Grant B and Newell J M, B C Ministry of Energy, Mines and Petroleum Resources, Paper 1996-1, pp. 277-294.

Ryan B and Khan M 1997 Maceral affinity of phosphorous in coals from the Elk Valley Coalfield, British Columbia; Geological Fieldwork 1997, B.C. Geological Survey and Fording Coal Limited, Calgary, Paper 1998-l, pp. 28-20.

Schimmelmann A, Mastalerz M, Gao L, Sauer P E and Topalov K 2009 Dike intrusions into bituminous coal, Illinois basin: H, C, N, O isotopic responses to rapid and brief heating; Geochim. Cosmochim. Acta 73 6264-6281.

Sengupta N, Guha P K S and Mukhopadhyay A 1979 Pattern of lower Gondwana sedimentation, Jharia Basin, a model; In:IVth International Gondwana Symposium, Vol. II, Hindustan Publ. Co., Delhi, pp. 617-625.

Seredin V V 1996 Rare earth element-bearing coals from the Russian Far east deposits; Int. J. Coal Geol. 30 101-129.

Seredin V V and Dai S 2012 Coal deposits as a potential alternative source for lanthanides and yttrium; Int. J. Coal Geol. 94 67-93.

Singh M P and Singh P K 1995 Mineral matter in the Rajmahal coals: Study through incident light microscopy and scanning electron micrography; J. Geol. Soc. India 46 557-564.

Singh P K, Singh G P and Naik A S 2010 Petrological considerations for beneficiation of Indian coal; J. Sci. Res. 54 51-60.
Singh A L, Singh P K, Singh M P and Kumar A 2015a Environmentally sensitive major and trace elements in Indonesian coal and their geochemical significance; Energy Source A 37 1836-1845.

Singh P K, Rajak P K, Singh M P, Naik A S, Singh V K, Raju S V and Ojha S 2015b Environmental geochemistry of selected elements in lignite from Barsingsar and Gurha Mines of Rajasthan, Western India; J. Geol. Soc. India $8623-32$.

Singh P K, Rajak P K, Singh M P, Singh V K and Naik A S 2016a Geochemistry of Kasnau-Matasukh lignites, Nagaur basin, Rajasthan (India); Int. J. Coal Sci. Technol. 3(2) 104-122.

Singh P K, Singh V K, Rajak P K, Singh M P and Naik A S 2016b Distribution and geochemistry of selected trace elements in the lignites of Cambay basin, Gujarat, Western India; J. Geol. Soc. India 88 131-146.

Spears D A 2012 The origin of tonsteins, an overview, and links with seat earths, fireclays and fragmental clay rocks; Int. J. Coal Geol. 94 22-31.

Stubbles J R 1986 Phosphorous and sulphur in steel making, Iron Steel Making, $\mathrm{PhD}$ thesis.

Swain F M 1970 Non-marine organic geochemistry; Cambridge University Press, Cambridge.

Swaine D J 1980 Trace element aspects of coal mining, preparation and storage; In: Environmental controls for coal mining - Proceedings of first national seminar (ed.) Hannan J C, Earth Resources Foundation, University of Sydney, pp. 264-274.

Swaine D J 1990 Trace elements in coal; Butterworth, London, 278p.

Varma A K and Mishra S 2005 Geological and petrographic characterization for phosphorous distribution in some coal seams of Jharia coalfield, Jharkhand, India; In: 57 th annual meeting of International Committee for Coal and Organic Petrology, ICCP Abstracts, Patras, Greece, $22 \mathrm{p}$.

Verma R P, Jaipuriar A M and Paul P R 1989 Compendium on updated and revised geology of Jharia coalfield (excluding TISCO \& IISCO properties); Central Mine Planning and Design Institute Ltd., Ranchi, India.

Wang X 2009 Geochemistry of Late Triassic coals in the Changhe Mine, Sichuan Basin, south western China: Evidence for authigenic lanthanide enrichment; Int. J. Coal Geol. 80 167-174.

Ward C R 1974 Isolation of mineral matter from Australian bituminous coals using hydrogen peroxide; Fuel 53220 221.

Ward C R 1978 Mineral matter in Australian bituminous coals; Proc. Australas. Inst. Min. Metall. 267 7-25.

Ward C R 2002 Analysis and significance of mineral matter in coal seams; Int. J. Coal Geol. 50 135-168.

Ward C R 2016 Analysis, origin and significance of mineral matter in coal: An updated review; Int. J. Coal Geol. 165 $1-27$.

Ward C R, Corcoran J F, Saxby J D and Read H W 1996 Occurrence of phosphorus minerals in Australian coal seams; Int. J. Coal Geol. 31 185-210.

Willett J C, Finkelman R B, Mroczkowski S, Palmer C A and Kolker A 2000 Semiquantitative determination of the modes of occurrence of elements in coal: Results from an international round robin project. In: Modes of occurrence 
of trace elements in coal. Reports from an international collaborative programme (ed.) Davidson R M, IEA Coal Research, London, UK (CD-ROM).
Zhou Y, Ren Y and Bohor B F 1982 Origin and distribution of tonsteins in late Permian coal seams of south western China; Int. J. Coal Geol. 2 49-77.

Corresponding editor: Partha Pratim Chakraborty 